\title{
Technical Feasibility Study on Utilization of Textile Sludge as a Cement Substitute in Rubber Mould Paver Block
}

\author{
Kaushal Patel ${ }^{1}$, Prof. (Mrs.) Reshma L. Patel ${ }^{2}$, Dr. Jayeshkumar Pitroda ${ }^{3}$ \\ ${ }^{1}$ Finalyear M. Tech. Student, Environmental Engineering, B.V.M. Engineering College, Gujarat, India \\ ${ }^{2}$ Associate Professor, Civil Engineering Department, B.V.M. Engineering College, Gujarat, India \\ ${ }^{3}$ AssistantProfessor, Civil Engineering Department, B.V.M. Engineering College, Gujarat, India
}

\begin{abstract}
In India, textile industries are one of the prime and eldest parts. An Enormous amount of water is been utilized by textile enterprises for its different operations and procedures, which creates perilous waste. High measure of sludge is produced while treating textile effluent. Managing of synthetic sludge in the textile effluent treatment plant has now turned into a noteworthy issue because of its colossal volume. The disposal and dumping is restricted by the pollution control board in light of the fact that environmental contamination. In this review an endeavor is made to discover the practicality of utilizing textile Effluent Treatment Sludge as cement substitute in M30 grade Rubber Mould Paver Blocks (RMPB). The Rubber Mould Paver Blocks (RMPB) cast with textile sludge a role as cement replacement material at $0 \%, 5 \%, 10 \%, 15 \%, 20 \%, 25 \%, 30 \%, 35 \%, 40 \%$ by the weight of cement. The compressive strength and abrasion resistance step by step diminish with increment in sludge and later it flops underneath coveted esteem when cement supplanted by textile Effluent treatment plant (ETP) sludge over $20 \%$.
\end{abstract}

Keywords: Textile Effluent Treatment Plant (ETP) Sludge, Sludge disposal, Solid Waste Management, Cement, Paver Block, Rubber Mould Paver Block (RMPB), Rubber Mould Textile Sludge Paver Blocks (RMTSPB)

\section{INTRODUCTION}

In India, textile industries are one of the prime and eldest sectors. An Enormous quantity of water is been used by textile industries for its various operations and processes, which generates hazardous waste. High amount of sludge is produced while treating textile effluent. Every day about 70 to 80 million tonnes of textile sludge is generated as a byproduct of 240 dyeing industries. 20 million tonnes of textile sludge is stored in each site. Management of chemical sludge in the textile and waste water treatment industries treatment effluent sludge has now become a major issue due to its huge volume. The disposal and dumping is banned by the pollution control board because environmental pollution.

Thus there is demand of an item which can be in part supplant the cement so in the event that we can utilize the textile effluent treatment plant sludge in replacement of cement then we can progressively get a material which can supplant the cement, which is financially cost effective. The sludge makes more negative segment and motivation from numerous points of view for as right disposal methods are not embraced. There is emerging need of alternative solutions for the sludge management. In the present review it's proposed to study the impact of addition textile sludge in rubber mould paver block.

The usage of Textile Effluent Plant Sludge as cement not only converts waste into manageable products as well as put a conclusion to its disposal and dumping issues. In the present examination, an endeavor is made to study the strength characteristics of Rubber Mould Textile Sludge Paver Blocks (RMTSPB).

\section{EXPERIMENTAL MATERIALS}

Following are the experimental materials for the research experimental work

\subsection{Textile Sludge}

The Textile ETP Sludge was gathered from Moon Fibers Pvt. Ltd. (21 $\left.{ }^{\circ} 02^{\prime} 14.7^{\prime \prime} \mathrm{N} 72^{\circ} 55^{\prime} 40.9^{\prime \prime} \mathrm{E}\right)$, Surat region, Gujarat state, India. The Sludge was gathered from its stockpiling premises. The Sludge 
Kaushal Patel et al.

had $9.66 \%$ moisture content. The sludge was sundried at average temperature of $32^{\circ} \mathrm{c}$ for $66 \mathrm{hrs}$. Figure 1 shows the Textile ETP sludge. Table 1 shows thechemical composition of Textile ETP sludge.

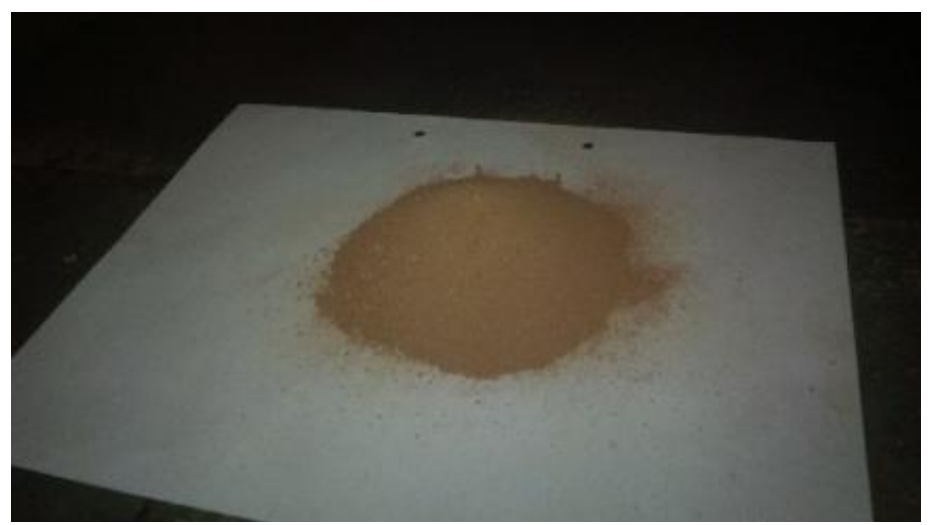

Figure1. Textile ETP Sludge

Textile ETP Sludge contains calcium $(\mathrm{CaO})$ and Silica $\left(\mathrm{SiO}_{2}\right)$. Textile ETP Sludge behaves like cement because of silica and magnesium properties. This silica and magnesium improve the setting of the concrete.

Table1. Chemical Composition of Textile Etp Sludge

\begin{tabular}{|c|c|}
\hline Chemical Composition & Result (\%) \\
\hline $\mathrm{SiO}_{2}$ & 2.56 \\
\hline $\mathrm{Fe}_{2} \mathrm{O}_{3}$ & 43.806 \\
\hline $\mathrm{Al}_{2} \mathrm{O}_{3}$ & 0.179 \\
\hline $\mathrm{CaO}$ & 39.613 \\
\hline $\mathrm{MgO}$ & 0.204 \\
\hline $\mathrm{SO}_{3}$ & 10.272 \\
\hline
\end{tabular}

\subsection{Cement}

The cement utilized for the present examination was Ordinary Portland Cement (OPC) Grade -53 (Hibond 53). It is conformed to the requirement of Indian Standard specification IS 456: 2000. Figure 2 shows Hi-bond 53 Grade Ordinary Portland Cement.The physical and chemical composition is given in Table 2 and Table 3 below.

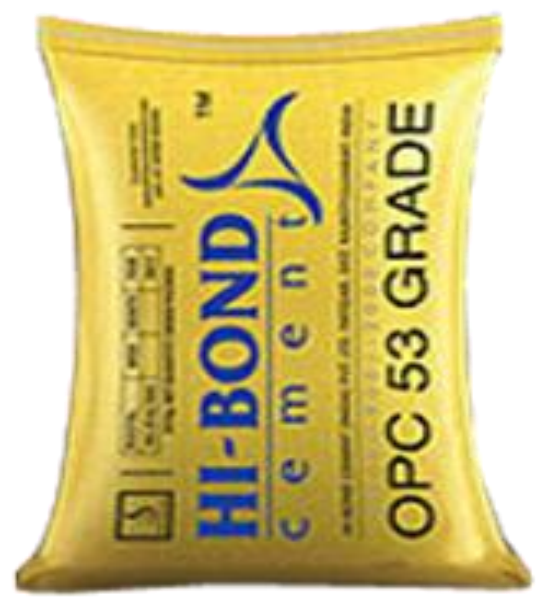

Figure2. Hi-bond 53 Grade OPC

Table2. Physical Properties of Hibond 53 Grade

\begin{tabular}{|c|c|c|}
\hline Test & \multicolumn{2}{|c|}{ Results } \\
\hline Fineness & 326 & $\mathrm{M}^{2} / \mathrm{kg}$ \\
\hline Initial Setting Time & 120 & Min \\
\hline Final Setting Time & 190 & Min \\
\hline
\end{tabular}


Technical Feasibility Study on Utilization of Textile Sludge as a Cement Substitute in Rubber Mould Paver Block

Table3. Chemical Composition of Hibond 53 Grade

\begin{tabular}{|c|c|}
\hline Chemical Composition & Result (\%) \\
\hline $\mathrm{SiO}_{2}$ & 21.04 \\
\hline $\mathrm{Fe}_{2} \mathrm{O}_{3}$ & 3.77 \\
\hline $\mathrm{Al}_{2} \mathrm{O}_{3}$ & 6.02 \\
\hline $\mathrm{CaO}$ & 62.93 \\
\hline $\mathrm{MgO}$ & 2.49 \\
\hline $\mathrm{SO}_{3}$ & 1.72 \\
\hline
\end{tabular}

\subsection{Fineaggregate}

Fine aggregate is a naturally occurring granular material composed of finely divided rock and mineral particles. Those fractions from $4.75 \mathrm{~mm}$ to 150 microns are termed as fine aggregate.Figure 3 shows fine aggregate.

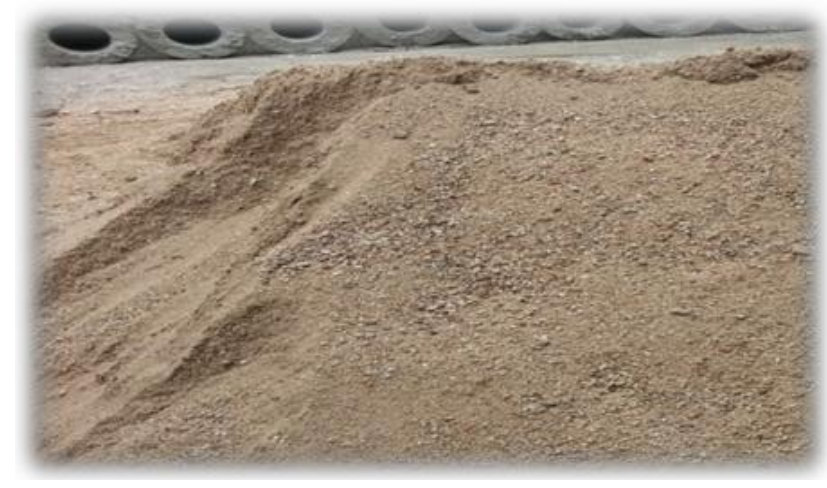

Figure3. Fine Aggregate

(Source: Galaxy India Pvt ltd.)

\subsection{Coarse Aggregate (Semi Grit)}

Coarse Aggregate (Semi Grit) is the heavier sand than typical sand and is very versatile sand used for many different tasks and jobs. Semi Grit is also ideal for building and it is one of the building sands that building companies use, principally as bedding material for paving. The size of the semi grit is less than $12 \mathrm{~mm}$. Figure 4 shows Coarse Aggregate (Semi Grit).

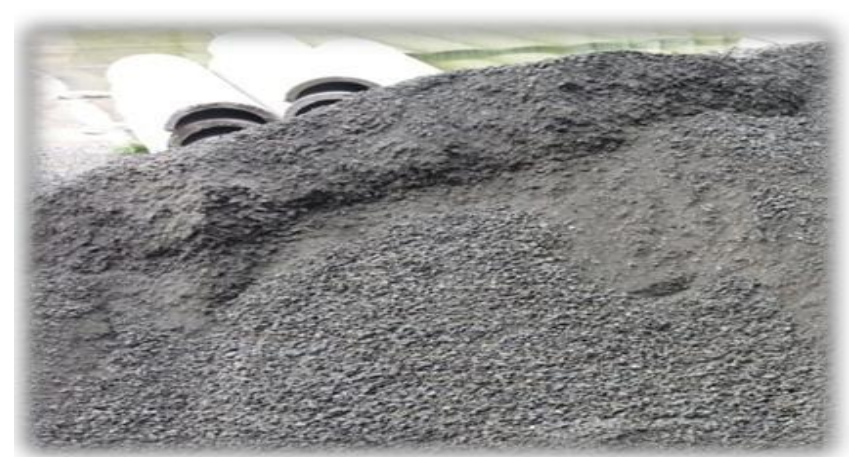

Figure4. Coarse Aggregate (Semi Grit)

(Source: Galaxy India Pvt ltd.)

\subsection{Water}

The water shall be clean and free from deleterious matter. It shall meet the requirements stipulated in IS 456:2000.

\section{DESIGN MiX}

Design Mix of M30 Grade with 60 mm thick Rubber Mould Paver Block (IS: 456-2000, IRC: SP: 632004)as shown in Table 4and same was used to prepare the various test samples Replacement of Cement with textile ETP Sludge. The design mix proportion is shown in Table 5. 
Kaushal Patel et al.

Table4. Design Mix of (M30 Grade) 60 Mm Thick Rubber Mould Textile Sludge Paver Block (Rmtspb)(Is: 4562000, Irc: Sp: 63-2004)

\begin{tabular}{|c|c|c|c|c|}
\hline Cement & F. A & C. A & Admixture & Water \\
\hline 410 & 685 & 1160 & 7 & 155 \\
\hline 1 & 1.67 & 2.83 & 0.017 & 0.38 \\
\hline
\end{tabular}

F. A. = Fine Aggregate, C. A. = Coarse Aggregate (Semi Grit)

Table5. Replacement of Cement with Textile Etp Sludgein Rubber Mould Textile Sludge Paver Block (Rmtspb)

\begin{tabular}{|c|c|c|c|c|c|c|c|}
\hline $\begin{array}{c}\text { Sr. } \\
\text { No. }\end{array}$ & $\begin{array}{c}\text { Replacement } \\
\text { Of Cement }(\boldsymbol{\%})\end{array}$ & Cement & $\begin{array}{c}\text { Textile Sludge } \\
(\mathbf{K g})\end{array}$ & F. A (Kg) & C. A (Kg) & Water & $\begin{array}{c}\text { Admixture } \\
\text { (Lit) }\end{array}$ \\
\hline A & 0 & 24.60 & 0 & 41.1 & 69.6 & 9.3 & 0.42 \\
\hline B1 & 5 & 23.37 & 1.23 & 41.1 & 69.6 & 9.3 & 0.42 \\
\hline B2 & 10 & 22.14 & 2.46 & 41.1 & 69.6 & 9.3 & 0.42 \\
\hline B3 & 15 & 20.91 & 3.69 & 41.1 & 69.6 & 9.3 & 0.42 \\
\hline B4 & 20 & 19.68 & 4.92 & 41.1 & 69.6 & 9.3 & 0.42 \\
\hline B5 & 25 & 18.45 & 6.15 & 41.1 & 69.6 & 9.3 & 0.42 \\
\hline B6 & 30 & 17.22 & 7.38 & 41.1 & 69.6 & 9.3 & 0.42 \\
\hline B7 & 35 & 15.99 & 8.61 & 41.1 & 69.6 & 9.3 & 0.42 \\
\hline B8 & 40 & 14.76 & 9.84 & 41.1 & 69.9 & 9.3 & 0.42 \\
\hline
\end{tabular}

F. A. = Fine Aggregate, C. A. = Coarse Aggregate $($ Semi Grit $)$

Where, A is without replacement of cement Rubber Mould Paver Block, B1 to B8 is replacement of cement by textile ETP Sludge in Rubber Mould Paver Block.

\section{EXPERIMENTAL METHODOLOGY}

\subsection{Testing Methodology}

Rubber Mould Textile Sludge Paver Block (RMTSPB) contains cement, Textile ETP Sludge, Fine aggregate, semi grit and admixture is utilized. In Rubber Mould Textile Sludge Paver Block (RMTSPB) cement is substituted with textile ETP sludge by $5 \%, 10 \%, 15 \%, 20 \%, 25 \%, 30 \%, 35 \%$ and $40 \%$ by weight of cement. For compressive strength test and abrasion resistance test there was 4 numbers of paver block has been casted. After around $24 \mathrm{~h}$ the specimens were placed at safe place and water curing was continued till the respective specimens were tested after 28 days for both tests.

\subsection{Compressive Strength Test Results [IS 15658:2006]}

Compressive strength tests were performed on compression testing machine using paver block samples. Four samples per batch were tested with the average strength values reported in this paper. The block has been stored in $24 \pm 4 \mathrm{~h}$ in water maintained at a temperature of $20 \pm 5^{\circ} \mathrm{C}$. The bearing plates of the testing machine shall be wiped clean. The specimens are aligned with those of the bearing plates. The load would be applied without shock and increased continuously at a rate of $15 \pm$ $3 \mathrm{~N} / \mathrm{mm}^{2} / \mathrm{min}$ until no greater load can be sustained by the specimen or delamination occurs. The maximum loads applied to the specimen were noted.The compressive strength results are compiled in Table6.

Table6. Comparative Experimental Results for Compressive Strength Test of Rubber Mould Textile Sludge Paver Block (Rmtspb)

\begin{tabular}{|c|c|c|c|c|}
\hline \multirow[t]{2}{*}{ Description } & \multirow{2}{*}{$\begin{array}{c}\text { Rubber Mould } \\
\text { Paver Block } \\
\text { Mixes }\end{array}$} & \multicolumn{3}{|c|}{$\begin{array}{l}\text { Average Compressive Strength } \\
\qquad\left(\mathrm{N} / \mathrm{mm}^{2}\right)\end{array}$} \\
\hline & & 7 days & 14 days & 28 days \\
\hline Standard RMPB & $\mathbf{A}$ & 22.59 & 29.57 & 36.99 \\
\hline \multirow{8}{*}{$\begin{array}{l}\text { Rubber Mould Textile Sludge } \\
\text { Paver Blocks(RMTSPB) }\end{array}$} & B1 & 20.86 & 26.30 & 33.19 \\
\hline & B2 & 18.62 & 24.74 & 30.95 \\
\hline & B3 & 17.67 & 23.62 & 29.40 \\
\hline & B4 & 16.98 & 22.42 & 28.02 \\
\hline & B5 & 15.26 & 21.04 & 26.55 \\
\hline & B6 & 14.92 & 20.61 & 25.86 \\
\hline & B7 & 14.23 & 20.00 & 25.00 \\
\hline & B8 & 13.28 & 18.19 & 23.11 \\
\hline
\end{tabular}


Technical Feasibility Study on Utilization of Textile Sludge as a Cement Substitute in Rubber Mould Paver Block

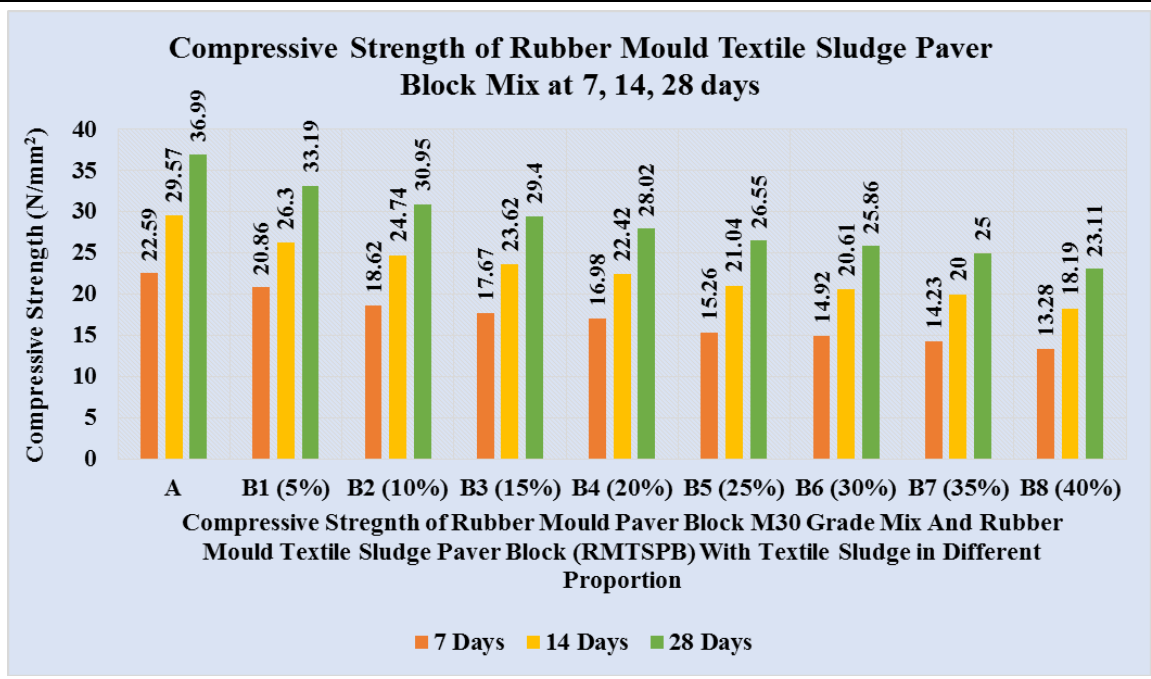

Figure5. Compressive Strength of Rubber Mould Paver Block M30 Grade Mix and Rubber Mould Textile Sludge Paver Block (RMTSPB) with Textile Sludge in Different Proportions

From above figure 5, it can be said that compressive strength of the M30 grade Rubber Mould Textile Sludge Paver Block (RMTSPB) mixes decrease with increase in sludge proportion. So optimum Textile Sludge content for maximum compressive strength was $20 \%$ textile sludge replaced by cement. For $20 \%$ B 4 mix shows $28.02 \mathrm{~N} / \mathrm{mm}^{2}$ compressive strength.

\subsection{Abrasion Resistance Test Results}

The abrasion resistance testresults are compiled in Table7.

Table7. Average Abrasion Resistance Test Results for All Paver Block Mixes At 28 Days

\begin{tabular}{|c|c|c|}
\hline Description & $\begin{array}{c}\text { Rubber Mould } \\
\text { Paver Block Mixes }\end{array}$ & $\begin{array}{c}\text { Average Abrasion Resistance for all Rubber Mould } \\
\text { Paver Block Mixes with/without Textile Sludge at } \\
\text { 28 Days (mm) }\end{array}$ \\
\hline \multirow{4}{*}{$\begin{array}{c}\text { Standard RMPB } \\
\text { Rubber Mould Textile } \\
\text { Sludge }\end{array}$} & B & 1.207 \\
\cline { 2 - 3 } Paver Blocks (RMTSPB) & B2 & 1.409 \\
\cline { 2 - 3 } & B3 & 1.505 \\
\cline { 2 - 3 } & B4 & 1.674 \\
\cline { 2 - 3 } & B5 & 1.788 \\
\cline { 2 - 3 } & B6 & 1.977 \\
\cline { 2 - 3 } & B7 & 2.157 \\
\cline { 2 - 3 } & B8 & 2.249 \\
\hline
\end{tabular}

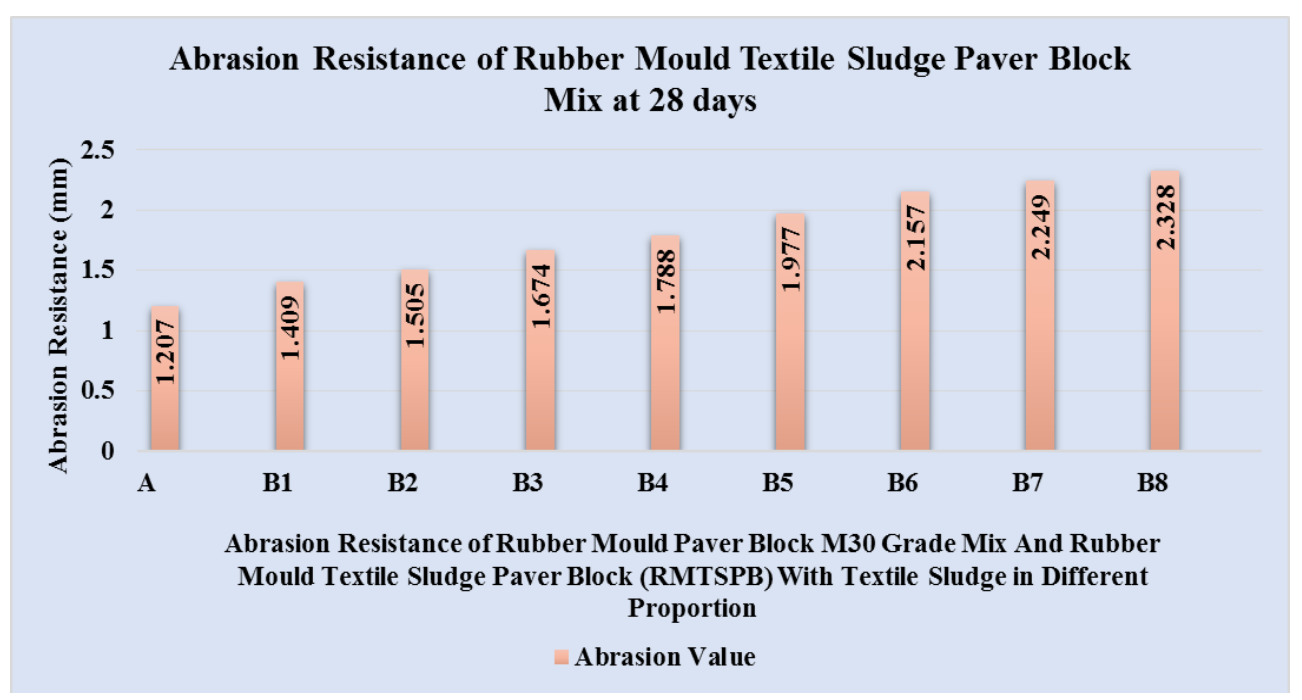

Figure6: Abrasion Resistance of Rubber Mould Paver Block M30 Grade Mix and Rubber Mould Textile Sludge Paver Block (RMTSPB) with Textile Sludge in Different Proportions 
From above figure 6, it can be said that Abrasion resistance of the M30 grade Rubber Mould Textile Sludge Paver Block (RMTSPB) mixes decrease with increase in sludge proportion. So optimum Textile Sludge content for maximum abrasion resistance was $20 \%$ textile sludge replaced by cement. For 20\% B4 mix shows $1.788 \mathrm{~mm}$ thickness decreased.

\section{Conclusions}

From the above experimental test, following conclusion is drawn:

a) The compressive strength of Rubber Mould Textile Sludge Paver Block (RMTSPB) at 28 days diminishes with increment in textile ETP sludge proportion. Maximum 20\% textile ETP sludge can be utilized to get compressive strength nearer to $30 \mathrm{~N} / \mathrm{mm}^{2}$.

b) The abrasion resistance of Rubber Mould Textile Sludge Paver Block (RMTSPB) at 28 days, after 22 rotation block thickness decrease with increase in textile ETP sludge proportion. For $20 \%$ sludge abrasion resistance $1.788 \mathrm{~mm}$ thickness is decreased.

c) From the above conclusions up to $20 \%$ textile ETP sludge can be utilized as cement substitute.

\section{ACKNOWLEDGEMENT}

The Authors thankfully acknowledge to Dr. C. L. Patel, Chairman, Charutar Vidya Mandal, Er.V.M.Patel, and Hon.Jt. Secretary, Charutar Vidya Mandal, Dr I. N. Patel, Principal, B.V.M. Engineering College, Mr. Palakbhai Patel, Owner of Galaxy India Pvt Ltd., Ankleshwar, Prof. R. L. Patel, Associate professor and coordinator PG (Environmental Engineering), Civil Engineering Department, B.V.M Engineering College, Vallabh Vidyanagar, Gujarat, India for their motivations and infrastructural support to carry out this research.

\section{REFERENCES}

[1] Ahamed S., Somasundar V., Pari S. "Utilization of Textile Effluent Treatment Plant Sludge in Construction Materials" International Journal of Informative and Futuristic Research, Vol.2 Issue 6 Feb 2015, and ISSN: 2317-1697

[2] Baskar R., MeeraSheriffa Begum K.M, , Sundaram S. "Characterization and Reuse of Textile Effluent Treatment Plant Waste Sludge in Clay Bricks Journal of the University of Chemical Technology and Metallurgy, 41, 4, 2006, 473-478

[3] Balasubramanian J., Sabumon P.C, lazar J. U, Ilangovan R. "Reuse of Textile Effluent Treatment Plant Sludge in Building Material”, Elsevier Waste Management 26 (2006) 22-28

[4] Jahangirdar S.S., Shrihari S., Manu B." Reuse of Textile Mill sludge in Cement Based Solid Blocks" International J. of Engg. Research \&Indu. Appls. (IJERIA).ISSN 0974-1518, Vol.5, No. III (August 2012), pp. 213-224

[5] Kulkarni G.J., Dwivedi A.K., Jahgirdar S.S. "Textile Mill Sludge as Fine Aggregate in Concrete" Global Journal of Researches in Engineering Industrial Engineering Volume 12 Issue 2 Version 1.0 Year 2012, ISSN: 2249-4596

[6] Kishore V. "Utilization of Sludge Concrete in Paver Blocks" International Journal of Emerging Treads in Engineering and Development, Issue 2, Vol.4 (May 2012), ISSN 2249-6149

[7] Lissy M., Sreeja M. "Utilization of Sludge in Manufacturing Energy Efficient Bricks" IOSR Journal of Mechanical and Civil Engineering (IOSR-JMCE) e-ISSN: 2278-1684, p-ISSN: 2320334X, Volume 11, Issue 4 Ver. III (Jul- Aug. 2014), PP 70-73

[8] Lekshmi S., Sasidharan S. "Experimental Investigation in the Use of Textile Sludge in Concrete" International Journal of Advances in Engineering \& Technology, Aug., 2015, ISSN: 22311963

[9] Palanisamy V. "Utilization of Textile Effluent Waste Sludge in Brick Production", International Journal of Sciences: Basic and Applied Research (IJSBAR) ISSN 2307-4531

[10] Patel H., Pandey S. "Explo1ring the Reuse Potential of Chemical Sludge from Textile Wastewater Treatment Plants in India-A Hazardous Waste", American Journal of Environmental Sciences 5 (1): 106-110, 2009 ISSN 1553-345X

[11] PatelKaushal, PatelReshma L., PitrodaJayeshkumar R., "Environmental and Technical Feasibility Study on Utilization of Textile Effluent Treatment Plant Sludge as a Construction Material: A Review", International Conference on Research and Innovations in Science, Engineering \& Technology (ICRISET - 2017) Organized by Birla Vishvakarma Mahavidyalaya Engineering 
College (An Autonomous Institution) Managed by Charutar Vidya Mandal Vallabh Vidyanagar, Anand, Gujarat, India,PP 05-09, Paper ID: ICRISET_PAPER_30, ISBN 978-93-84339-38-8, Published by: RIA Publishing House, Vallabh Vidyanagar, $17^{\text {th }}-19^{\text {th }}$ February 2017

[12] Raghunathan T. Gopalsamy P, Elangovan R "Study on Strength of Concrete with ETP from Dying Industry", International Journal of Civil and Structural Engineering Volume 1, no 3, 2010 ISSN 0976-4399

[13] Sandesh N.U, Varun K., Prashanth V.P. "A Study on Engineering Properties of Textile ETP Sludge Based Cement Concrete" International Journal of Innovations in Engineering and Technology (IJIET) Volume 4 Issue 4 December 2014, ISSN: 2319 - 1058

[14] Senthilkumar K., Sivakumar V., Akilamudhan P. "Experimental Studies on Disposal of Various Industrial Solid Wastes" Modern Applied Science Vol.2, No.6, November 2008

[15] Sudheesh C., Kumar T., Kumar S. "Effect of Compressive Strength on Concrete by partial Replacement of Cement with Textile Sludge and polypropylene Fibers" International Journal of ChemTech Research, Vol.8, No.4, pp. 2219-2226, ISSN: 0974-4290

[16] Sathanandham T., Vijayan V., Kumar D." Studies on Effective and Ecofriendly Utilization of Textile and Dying Effluent Sludge in Construction Industry" International Journal of Innovative Research and Studies, Vol.4 Issue 3 March 2015, ISSN: 2319-9725

\section{AUTHORS' BIOGRAPHY}

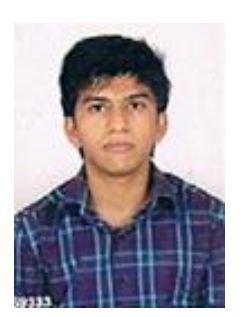

Kaushal Patel, received his Diploma in Civil Engineering from S.T.B.S. College of Diploma Engineering (Surat), Gujarat Technological University, in 2012. And Bachelor of Technology degree in Civil Engineering from the Charotar University of Science and Technology (CHARUSAT) - Changa, in 2015. At present, he is final year student of Master's Degree in Environmental Engineering from Birla Vishvakarma Mahavidyalaya, Gujarat Technological University.

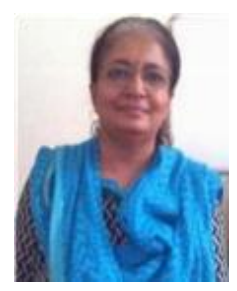

Prof. Reshma L. Patel, received her Bachelor of Engineering degree in Civil Engineering from the Birla Vishvakarma Mahavidyalaya, Sardar Patel University in 1991. In 1993 she received her Master's Degree in Civil (Environmental) Engineering from Birla Vishvakarma Mahavidyalaya, Sardar Patel University. She joined Birla Vishvakarma Mahavidyalaya Engineering College as a faculty in 1994, where she is Associate Professor of Civil Engineering Department with a total experience of 22 Years in the field of Research, Designing and education. She is guiding M.E. (Environmental Engineering) Thesis work in the field of Civil/ Environmental Engineering. She has published many papers in National/ International Conferences and International Journals.

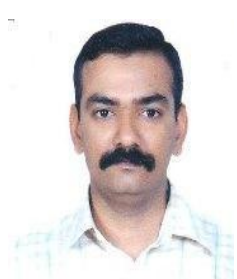

Dr. Jayeshkumar R Pitroda, received his bachelor of engineering degree in Civil Engineering from Birla Vishwakarma Mahavidyalaya Engineering College, Sardar Patel University in 2000. In 2009 he received his master's degree in Construction Engineering and Management from Birla Vishwakarma Mahavidyalaya Sardar Patel University. In 2015 he received his Doctor of philosophy (Ph.D.) degree in Civil Engineering from Sardar Patel University. He joined Birla Vishwakarma Mahavidyalaya Engineering College as a faculty in 2009, where he is Assistant Professor of Civil Engineering Department with a total experience of 16 years in the field of research, designing and education. He is guiding M.E. (Construction Engineering and Management) thesis work in the field of Civil / Construction Engineering. He has published many papers in National / International Conferences and International Journals. He has published seven Research Books in the field of Civil Engineering, Rural Road Construction, National Highways Construction, Utilization of Industrial Waste, Fly Ash Bricks, Construction Engineering and Management, Eco-friendly Construction. 